\title{
Strategies for student engagement in remote online learning. A case study of Northern Cyprus
}

Estrategias para la participación de los estudiantes en el aprendizaje en línea de manera remota. Un estudio de caso de Chipre del Norte

Chinaza Solomon Ironsi

Near East University - Cyprus

Lefkosia, Cyprus

solomon.chinaza@neu.edu.tr

\begin{abstract}
In unprecedented times like this when societies are experiencing lockdowns, social, and physical distancing, remote online learning becomes the only option for most educational institutions. There is a need for English Language Teaching practitioners to devise strategic means either through technology or without to meaningfully engage the students. This study examines learners' engagement strategies used during remote online learning at Northern Cyprus. To achieve this, a mixed research design was used to elicit information from 63 ELT teachers who were purposively chosen for this research. A 3-credit English language course was used for the study. The course was taught and teachers deployed the use of engagement tools, skills, and resources during the remote online learning teaching period, which lasted for 8 weeks and 2 days. A structured questionnaire consisting of two sections; A and B were used to elicit information on the resources used for student engagements and its effectiveness as well while a semi-structured interview question was used to interview randomly chosen participants. These instruments were faced and the construct validated while the questionnaire was piloted, a Cronbach alpha reliability index of 0.77 was obtained. Descriptive analysis was used to analyze the questionnaire to determine the mean responses of the participants with regards to resources used for student engagement and their effectiveness. Findings obtained were used to conclusions that online resources like Padlets, Mentimeter, nearpod, Flipgrid, Zoom breakout room are effective and efficient tool for student engagement during remote online learning. Project based learning and collaborative based teaching are strategies that could be adopted to enhance student engagement while teaching.
\end{abstract}

Keywords: Student engagement; Remote learning; online learning; COVID-19; Northern Cyprus

\section{RESUMEN}

En tiempos sin precedentes como éste, en los que las sociedades están experimentando bloqueos, distanciamientos sociales y físicos, el aprendizaje remoto en línea se convierte en la única opción para la mayoría de las instituciones educativas. Es necesario que los profesionales de la enseñanza del inglés conciban medios estratégicos, ya sea a través de la tecnología o sin ella, para involucrar de forma significativa a los estudiantes. Este estudio examina las estrategias de compromiso de los estudiantes utilizadas durante el aprendizaje remoto en línea en el norte de Chipre. Para lograrlo, se utilizó un diseño de investigación mixto para obtener información de 63 profesores ELT que fueron elegidos a propósito para esta investigación. Se utilizó un curso de inglés de 3 créditos para el estudio. El curso se impartió y los profesores desplegaron el uso de herramientas de compromiso, habilidades y recursos durante el período de enseñanza del aprendizaje remoto en línea, que duró 8 semanas y 2 días. Se utilizó un cuestionario estructurado que constaba de dos secciones; A y B se utilizaron para obtener información sobre los recursos utilizados para la participación de los estudiantes y su eficacia, mientras que una pregunta de entrevista semiestructurada se utilizó para entrevistar a participantes elegidos al azar. Se enfrentaron estos instrumentos y se validó el constructo mientras se probaba el cuestionario, se obtuvo un índice de fiabilidad alfa de Cronbach de 0,77. Se utilizó un análisis descriptivo para analizar el cuestionario a fin de determinar las respuestas medias de los participantes con respecto a los recursos utilizados para la participación de los estudiantes y su eficacia. Los resultados obtenidos se utilizaron para llegar a la conclusión de que los recursos en línea como Padlets, Mentimeter, nearpod, Flipgrid, Zoom breakout room son una herramienta eficaz y eficiente para la participación de los estudiantes durante el aprendizaje en línea a distancia. El aprendizaje basado en proyectos y la enseñanza basada en la colaboración son estrategias que podrían adoptarse para mejorar la participación de los estudiantes mientras enseñan.

Palabras clave: Compromiso de los estudiantes; Aprendizaje a distancia; Aprendizaje en línea; COVID-19; Chipre del Norte 


\section{INTRODUCTION}

The COVID-19 outbreak caused many disruptions in our educational institutions, leading to the closure of these educational facilities. It is believed that more than 1.700 billion learners were currently affected by the pandemic outbreak as a result of the closure of schools (Daily Sabbah, 2020). It is widely reported by the UNICEF monitoring team that more than 130 countries have implemented a closedown of schools pending when the cure for the pandemic will be available. This closure has made a lot of schools resolve to online teaching and remote online learning (The University of Kyrenia, 2020; Muhammed, 2020) stressing both the tutors and learners. This sudden switch has caused a switch from traditional classroom learning to online learning, the unpreparedness involved in this switch is an issue to ponder on as there is need to ascertain the level of preparedness of instructors and learners for this dynamic change. This study upholds that online learning during this pandemic is challenged with a lot of setbacks ranging from internet connectivity issues, availability of internet for students, equality in learning, material selection, anxiety among students, resources for online learning, and student engagement during online learning. Research on anxiety has shown that high anxiety level impedes on good academic performance of students (Ironsi, 2017). Very limited research has been carried out to examine these issues to seek for ways to tackle them. Because of this, there is need for our educational facilities to re-strategize the means of lesson delivery to ensure that quality education is maintained even during these unprecedented times of learning by carrying out studies that will proffer solutions to these looming issues, this is an area where this present study becomes useful. The new virtual environment used as a platform of learning do has an impact or changes the way students engage and learn which may be a result of stress, remote learning, or sudden switch from traditional to online learning (Paulsen \& McCormick, 2020). This may cause students disengagement as at such affect the way they learn. This study intends to examine possible strategies that could be adopted in order to enhance student engagement during remote online learning.

1.1 Background of study

It would be of the essence to describe the educational setting of Northern Cyprus (NC) as usually legislated by the Turkish Republic of Northern Cyprus Ministry of Education. The educational system of Northern Cyprus consists of pre-school, primary school, secondary, and higher education (Universities) (Hale \& Ali, 2019). This small island builds its education on platforms of universality and equality, right for mandatory education and equal opportunity for all among others, they believe in life-long learning is usually very strong (Shola, Selira \& Mustafa, 2011). It is pertinent to state that the higher education sector has contributed immensely to the growth of the economy because of a high influx of foreign students who travel from more than sixty countries to study at NC (Hale et al., 2019). It is adjured that the GDP of NC was $\$ 14.768$ US dollars in 2007 with the educational sector contributing almost half to its entire GDP. This has made most universities to adopt a multicultural approach to teaching and learning and has created room for a multicultural atmosphere of learning that allows foreign students to meet each other and learn about their varying cultures as well. This study believes that the outbreak of the COVID 19 pandemic has hampered and affected academic activities in most universities in NC, thwarting the dreams of millions of foreign students who intend to study abroad - this could cause demotivation among students and possibly affect their zeal towards learning. In this light, there is a need for these demotivated students to be carefully engaged in a remote online learning platform to ensure that learning is taking place.

However, the outbreak of the pandemic has a lot of disruptions in educational activities, foreign students who travel abroad to these countries for study and also to learn of others' cultural heritage are victims of social and physical distancing. This study believes that these arrays of foreign students may show loss of interest towards learning, much more a sudden switch to remote online learning which they were not prepared for a few months ago-this seems more challenging. Adequate and appropriate strategies are essential for student engagement during these times and negligence may lead to demotivated students who only learn to pass examinations and acquire good grades. Online learning has gained momentum in North Cyprus and has been used since 2006 (Shola et al., 2011). Other studies do suggest that the use of flipped learning has achieved a lot in teaching and learning in North Cyprus (Tugun, Uzunboylu, \& Ozdamli, 2017). It is believed that flipped learning has enhanced more collaborative and interactive learning during the learning process, giving learners the space for mastery learning (Odo \& Eze, 2017). Though there are yet to be studies that examine the adoption or use of flipped learning during this pandemic outbreak and 
the achievements thereof, this will assist Xray teaching methodologies used during this pandemic period, ascertain their strengths and weakness.

After the outbreak of the pandemic, the Turkish Republic of Northern Cyprus government gave an ultimatum for all educational institutions to carry out teaching and learning via online mode as they remain closed, observing social and physical distancing, this instruction was announced on $20^{\text {th }}$ March 2020 (Yakin Dogu Universitesi, 2020). This rapid switch made universities announce the use of online learning as the learning platform for their students thereby encouraging students to register to access lessons (The University of Kyrenia, 2020). There was no opportunity to engage the instructors or equip them with the necessary technological tools required to make this switch to achieve instructional objectives, a time instructional objectives were redefined to meet up with the recent situation. This situation introduces the need for teachers and students to work collaboratively to ensure that learning occurs during this challenging time. The instructors were able to achieve quality instruction through the use of quality online teaching resources, and expertise in classroom management. One of the challenges of remote online teaching and learning is the need to motivate and stimulate students to learn, participate and contribute during lessons as were the case in traditional classroom scenarios (Sridharan \& Bond, 2019). This study believes that the case of North Cyprus was not different as there was a need to motivate foreign students towards learning. To do this, the excellent use of engagement skills and tools were necessary to achieve set or redefined instructional objectives (Karafil \& Oguz, 2019). Such tools or skills may include;

\footnotetext{
Skillfully presenting information in a variety of ways to meet learners' different learning styles either kinesthetic, audio, textual, and so on.

Collaborative peer work by breaking out the learners into different breakout rooms to engage them (Zoom break out rooms)

Making the learning experience relevant to the learner by allowing the students to personalize it either through the use of artificial intelligence (AR resources).

Implementing peer teaching/ presentations and forum for learners to ask questions through polls (using Mentimeter)

Implementing short self-graded quizzes to ascertain the extent to which learning is occurring (using Nearpod, Boom Cards)
}

This study believes that the use of these engagement skills/tools would assist in enhancing student's engagement in a remote online teaching scenario especially during this pandemic outbreak.

\subsection{Theoretical framework}

The need for student's engagement cannot be overemphasized especially during such periods of the pandemic outbreak where remote online learning becomes a viable tool and platform for learning. Student engagement is vital in every learning environment as it keeps the students motivated, engaged, and focused throughout the language learning process, much more in current situations where learners have to learn remotely. This research hinges on the Engagement theory which suggests that students should be meaningfully involved either through interactive tasks, collaborative projects to enhance authentic focus during learning (Mavromoustakos \& Kamal, 2018). This theory affirms that student engagement can occur with or without the use of technology (Philp and Duchesne, 2016) though other studies do suggest that the use of technology makes it more efficient and easier to achieve (Maia, Figueiredo, \& Serey, 2019; Sridharan \& Bond, 2019). This aim of engagement theory is to encourage and motivate students during the learning process (Paulsen and McCormick, 2020) which could be an effective tool to use in teaching during these unprecedented times of COVID 19 pandemic. This study aligns with this theory and asserts that motivation as the key ingredient of engagement theory would be a useful tool in stimulating and arousing the interest of learners during remote online learning. Studies adjure that when students are motivated to learn, lessons become more meaningful to them stimulating their interest to learn and retain information transferred to them. In challenging times with new virtual environments, engaging students becomes necessary especially in situations where students are demotivated as a result of stress caused 
by the outbreak of the pandemic, and the sudden switch to remote online learning (Groves, Sellars, Smith \& Barber, 2015). This study suggests that to achieve quality teaching and learning during this pandemic outbreak, there is a need to meaningfully engage students either through the use of technologies or without technologies. This study will examine various strategies either technological or otherwise that could be adopted towards engaging students in remote online learning during COVID 19 pandemic outbreak.

\subsection{Literature reviews}

It is vital to say that in remote online learning; student engagement is necessary. In achieving this there is a need to follow certain principles to engage learning in remote online learning (Stone, 2019). Previous research showed that certain principles should be adopted while trying to enforce engagement and this is usually carried out through learning by collaboration (Demosthenous et al., 2020), a series of recent studies has indicated that activities in the classroom must foster teamwork and show team effort as this unveil certain social skills of learner (Ekblaw, 2016). Previous studies have shown that there is need for learners to engage in constant communication with one another planning on how to execute a task as a team collaboratively (Demosthenous et al., 2020; Groves, 2015). There have been numerous studies to investigate project-based learning and they assert that in most cases collaboration is achieved through project-based activities which mandate all learner to participate in executing the project (Ekblaw, 2016; Ragusa \& Crampton, 2018). During this period, students are active and creative contributions to the entire development and execution of the project (Ekblaw, 2016). They learn how to think, ask questions, work with each other towards executing a task, this engages them throughout the lesson session. Several studies suggest that the instructors play a paramount role in designing captivating and interesting classroom activities that would motivate the student to encourage them to actively interact during lessons (Redzuan et al., 2016; Mavromoustakos \& Kamal, 2018). Prior research suggests that the instructor ought to design interactive task, classroom activities that are worthwhile and authentic task to meaningfully engage students during an online lesson (Toro-Troconis et al., 2019), Seminal contributions have been made by a recent research which opine that such creative tasks assist keep the students focused and motivated throughout the learning period (Stone, 2019), yet a similar study agree that consistency in carrying out these engagements makes the online learning a worthwhile experience (Sridharan \& Bond, 2019). This study affirms that the application of these strategies would help engage students in online remote learning to keep students motivated during this period of social and physical distancing as a result of the pandemic outbreak.

More so, previous study has emphasized that engagement is seen as the use of technology to arouse the interest of students during online learning (Ritchhart et al., 2011). Studies of on engagement are well documented, it is also well acknowledged that scholars have argued that student engagement can be with or without the use of technology though technology makes it easier and fun (Philp \& Duchesne, 2016; Demosthenous et al., 2020). A number of authors have recognized that careful selection of learning materials is vital for successful student engagement as the teacher needs to plan the kind of materials to use in stimulating the interest of learners while learning. Some authors have also suggested that the use of technological tools and platforms is becoming common especially during this untimely and sudden switch from traditional classroom teaching to remote online teaching (Paulsen \& McCormick, 2020; Mavromoustakos \& Kamal, 2018). This has been discussed by a great number of authors in literature yet they assert that technological based systems are being used to appeal to learners four sense while learning either through self-graded quizzes, online games, clickers, mentimeters, and so on. Some literature review shows that mentimeter is in-class audience polling technology that allows students to share their views on a particular question, the students remain anonymous while using this tool either for duringclass assessments to check comprehension of what is being taught or during discussions, the majority of current research has studied this tool and uncover that Mentimeters increase students' performance during an online class and improves the rate of retention of what is being taught (Beth, 2020). As has been previously reported in the literature, Mentimeters are vital technological tools that could be used for student engagement during remote online learning. 
Most early studies as well as current work believe that fostering group interaction is vital in online learning and the use of technological tools like Padlets, Flipgrid, Vocaroo, and Zoom breakout rooms is very effective (Kleinsmith, 2017; Beth, 2020; Paulsen \& McCormick, 2020). A large number of existing studies in the broader literature have examined and do posit that these technological tools are used to stimulate critical thinking among learners which encourages the learner to acquire critical thinking skills which is essential as one of the needed 21 $1^{\text {st }}$-century skills (Ekblaw, 2016; Mavromoustakos \& Kamal, 2018). There exists a considerable body of literature on which posit that learners can make use of Padlets as an online space to share their ideas and thoughts on a topic that usually stimulates discussions (Beltrán-Martín, 2019; Beth, 2020). In short, the literature pertaining to student engagement strongly suggests that learners could be encouraged to share their opinions or thoughts using the springboards which the teacher reads and discusses with everyone (Kleinsmith, 2017). It was reported in literature that learners feel engaged and motivated when their thoughts are being discussed and thus motivates them to share more and learn more (Fuchs, 2014). For example, research has provided evidence for the use of technological tool for student engagement, they acknowledge that Padlet, Flipgrid achieves almost the same thing as Mentimeter by allowing for thoughts to be shared and discussed while speaking and listening skills can be enhanced using these online technological tools especially Vocarroo which could be integrated into the educational Learning Management System platforms like Google Classroom, Edmodo or Moodle. There is a wide choice of tools to use which is available in the literature, the list is endless as there are lots of technological teaching and learning resources available for the teacher and learner to use during remote online learning, yet few studies are in existence on possible strategies to apply especially during school periods of the outbreak of COVID-19 pandemic. Teaching these categories of learners through tactful and careful use of strategies like student engagement becomes vital to achieving the core objectives of each lesson, motivating them, and assisting them to enjoy learning in remote online environments.

\subsection{The Present Study}

The need for student's engagement during remote online learning has been unveiled as discussed by researches mentioned above (Paulsen \& McCormick, 2020; Mai et al., 2019; Karfil et al, 2019,). This study has further asserted that there is need for careful selection of teaching and learning materials to be carried out by the instructors to choose, design and implement appropriate tools that will stimulate and motivate the students to learning especially in times of social and physical distancing where learners have to stay at home and learn. This paper believes that numerous engagement tools, resources, and skills are available to the instructors to choose and use during online lessons. Given this, the present study intends to examine the use of these instructional strategies either in form of resources, skills, or technological tools in fostering learner's engagement in remote online learning during the pandemic outbreak. To achieve this, these research questions were investigated

- What resources, skills, and tools were used during remote online learning?

- How effective were these resources when used during remote online learning?

- What are the perceptions of learners on the use of resources/technology during remote online learning?

\section{METHODS}

\subsection{Research Design}

This study adopted a qualitative research mixed-method research design for the study. This method uses both qualitative and quantitative means to elicit information from participants (Yildirim \& Simsek, 2011). The study believes that this research design will assist in eliciting useful information on the instructional strategies, tools, and resources used in student engagement in remote online learning especially during this pandemic outbreak. This study will collect data through the use of questionnaires and interviews in sampling the mean responses of participants with regards to the research questions. A 3-credit unit 
English language course which was already used for teaching before the coronavirus outbreak and was used for the study. The course was taught during the period of coronavirus using remote online learning. Certain instructional engagement tools, skills, and resources were deployed during every virtual classroom session to motivate students and arouse their interest throughout learning, this lasted for 8 weeks and 2 days. Afterward questionnaires and interviews were used to elicit information on the objective of this study.

\section{Participants}

Participants used for this study were 63 English Language Teaching (ELT) preservice teachers studying in a private university in North Cyprus. They were chosen through a purposive sampling method to ensure that participants chosen were those using remote online learning during this pandemic. For the interviews, 12 participants were randomly selected. Informed consent was received from the students before commencing the research and all the participants stated their willingness to participate in the research. For the interviews

\section{Data Collection}

A structured questionnaire and semi-structured questions were used as the instrument for data collection. The questionnaires consist of section $\mathrm{A}$ and $\mathrm{B}$, the first section consist of 12 question items whereas the second section consists of 8 questions. The questionnaire consists of 20 items that were designed to meet the objectives of the study. The section A of the questionnaire was structured on a 5 point Likert type scale of Always (5) often (4) sometimes (3) Rarely (2) and Never (1) and used to answer the first research question, while the second research question was structured on a 3 point Likert type scale of Very effective (3) Effective (2) and Not effective (1) and were used to measure the effectiveness index of using online teaching resources across 8 scales. More so, 5 Interview questions were used to answer the third research question on the perception of learners on the use of engagement resources and technologies during online learning. These questionnaires were face validated by two experts in the field on education to check the wording of the question items and ensure that they measure what they intend to measure. To ensure the reliability of the questionnaire, it was first administered to 20 preservice teachers who were randomly selected for this purpose, the questionnaire was collected after one week and analyzed for reliability, a Cronbach alpha index of 0.77 was obtained which suggest that the instrument was reliable enough to measure what it intends to measure as asserted by Creswell (2003). The interviews were scheduled through zoom, it was recorded and later on transcribed.

\section{Data Analysis}

The questionnaire was analyzed to determine the mean responses of the participants on resources, skills, tools used during online learning, and also the ascertain the effectiveness of these resources and tools used during remote online learning. The interviews were transcribed and the comments of the participants were used to make valid pedagogical conclusions.

\section{RESULTS AND FIGURES}

Table 1, presents the mean responses of participants on the resources, skills, and tools used during remote online learning. The above results indicated that a mean value of 4.00 (0.19) and 4.55 (0.61) was obtained when participants were asked to indicate if zoom application and break out rooms were used during online remote lessons. The results indicated that participants acknowledged that zoom application and breakout rooms were used by the teacher, break out room was used for group work and projects. The table showed that a mean value of 4.02 (0.69) was obtained when the participants were asked to indicate if Nearpod application was used for self-graded assessment. Also, the table suggested that games, use of padlets application, Mentimeter, flipgrid, boom cards, were the technological applications used by the instructors to teach and engage the student during remote online learning especially during this pandemic period, the average mean value of 4.00 affirming that they were used most often during lessons. The study taught that the use of vocaroo for recording opinions would be a useful tool towards engaging students 
in online remote learning, results indicated otherwise as a mean value of 2.35 (1.88) was obtained for this item which asserts that vocaroo technological application was rarely used for teaching.

More so, the table also indicates that instruction skills like the use of project and task by the teachers were more often used strategies during the online lessons, a mean value of 4.69 (0.34) was obtained which indicated so. When the participants were asked to indicate the extent to which peer teaching was used as a resource to engage students during online learning, a mean value of 2.56 (1.24) was obtained which is an indication that peer teaching was not used. The table indicated that a mean value of 4.34 (0.57) was obtained when participants were asked to indicate to the extent to which the teacher allowed interaction among the student. This result affirmed that the teacher often allowed the students to engage in interaction during lessons.

\section{SECTION A}

RQ1: What resources, skills, and tools where used during remote online learning?

Table 1: Mean responses of learners on resources, skills, and tools used during remote online learning

\begin{tabular}{|c|c|c|c|}
\hline Scale & $\mathbf{N}$ & Mean & SD \\
\hline Zoom application was used during lessons & 63 & 4.00 & 0.19 \\
\hline $\begin{array}{l}\text { The teacher uses Zoom break out room for group work/ } \\
\text { projects }\end{array}$ & 63 & 4.55 & 0.61 \\
\hline We used Nearpod application for self-graded assessment & 63 & 4.02 & 0.69 \\
\hline Games were used during lessons & 63 & 4.85 & 0.95 \\
\hline $\begin{array}{l}\text { Padlet was used to share the opinions of students during } \\
\text { lessons }\end{array}$ & 63 & 4.27 & 0.12 \\
\hline $\begin{array}{l}\text { The teachers made an audio recording with vocaroo and } \\
\text { the students responded to the discussion by making their } \\
\text { recording }\end{array}$ & 63 & 2.35 & 1.88 \\
\hline Mentimeter was used to seek our opinions on a topic & 63 & 4.18 & 0.68 \\
\hline We discussed topics in groups using flipgrid & 63 & 4.79 & 0.78 \\
\hline $\begin{array}{l}\text { Boom cards were used in between lessons to ensure students } \\
\text { are learning }\end{array}$ & 63 & 4.88 & 0.87 \\
\hline The teacher introduces projects/tasks to be accomplished & 63 & 4.69 & 0.34 \\
\hline Peer teaching was effective during online learning & 63 & 2.56 & 1.24 \\
\hline $\begin{array}{l}\text { The teacher allowed more interaction by the students during } \\
\text { lessons }\end{array}$ & 63 & 4.34 & 0.57 \\
\hline
\end{tabular}

Source: Statistical Package for the Social Science Analysis Result

Table 2 above presents the mean responses of participants on the effectiveness of resources used in teaching during remote online learning. When participants were asked to indicate the effectiveness of teaching resources towards achieving the lesson objective, a mean value of 4.77 (0.78) was obtained, an indication that the use of resources assisted in actualizing the lesson objectives. This result reflects on the other question items as this study adjures that in a lesson were lesson objectives are achieved, classroom activities ought to be well organized, enhancing collaborative learning and active interaction among the students. This aligns with these results obtained as a mean value of 4.65 (0.69) was obtained suggesting that classes were organized, a mean value of 4.02 (0.41) was obtained which was an indication that there was collaborative learning, and a mean value of 4.67 (0.72) was obtained implying that there were active interactions among the students while engaging in remote online learning.

However, the table indicated that when the participants were asked on the clarity of videos used during the remote online learning as well as the quality of audio used, a mean value of 2.24 (1.02) was obtained 
which indicated that the videos were not very clear to achieve effective teaching and learning. Again, a mean value of 2.67 (1.46) was obtained which implied that the audio qualities were not of high quality during remote online learning. The table shows that a mean value of 2.79 (1.52) was obtained when which was an indication that the student experienced difficulties while trying to connect the resources during remote online learning.

\section{SECTION B}

RQ2: How effective were these resources when used during remote online learning?

Table 2: Mean responses of learners on the effectiveness of resources used during remote online learning

\begin{tabular}{|c|c|c|c|}
\hline \multirow[b]{2}{*}{ Effectiveness index scale } & $\mathbf{N}$ & M & SD \\
\hline & & & \\
\hline The use of teaching resources achieved lesson objectives & 63 & 4.77 & 0.78 \\
\hline The use of teaching resources made classroom activities more organized & 63 & 4.65 & 0.69 \\
\hline The use of teaching resources enhanced collaborative learning & 63 & 4.02 & 0.41 \\
\hline Videos were clear during lessons & 63 & 2.24 & 1.02 \\
\hline The resources had a high audio quality & 63 & 2.67 & 1.46 \\
\hline It was easy to connect the resource application during live sessions & 63 & 2.79 & 1.52 \\
\hline Interactions using teaching resources was clear and interactive & 63 & 4.67 & 0.72 \\
\hline Interactions using online teaching resources was understandable & 63 & 4.52 & 0.62 \\
\hline
\end{tabular}

Source: Statistical Package for the Social Science Analysis Result

\section{Interview Questions}

As mentioned earlier on 12 participants were randomly selected to participate in the interview which was conducted using the zoom application. The questions were carefully read for them and their opinions were recorded and transcribed. The results are presented below;

\section{Q1. What are your thoughts on the use of technological resources during remote online learning?}

The interviewees narrated their thoughts on the use of technological devices during lessons. They indicated that the use of this technological tool was new to them and at first very difficult to understand and use though they became conversant with them. One of the participants T7 responded

“...using these technologies is difficult to understand how they operate and we did not know it before"

Another commented T5;

"It was very difficult to understand what the teacher wanted us to do with the tools but later on it became easy to understand and apply, it helped me".

The students affirmed that the use of these skills resources and tool helped make lesson more fun. They further stated that they were engaged throughout the lessons as they were very busy carrying out the task as if they were in the traditional classroom. In the words of T10, he puts it this way; 
"I was troubled when we were asked to register on the Moodle platform for online lessons and I was discouraged, at first it was difficult but later on the lessons were fun as the teacher used lots of games and resourceful materials to ensure that we enjoyed the lessons".

Another participant T1 explained;

"I'm very thankful to my teacher who helped us during this semester by guiding us on how to use the different games and applications like padlet during lessons, I did not feel left out of the class because the teacher always encouraged us to interact with each other, that was lovely"

Another stated;

"I think the whole experience was lovely, I like the breakout sessions where we have to discuss the topic in a particular room of 5 , that was great, it seemed as if we were in the classroom, that was so engaging, technology has done a lot for education"

Responses from these participants was an indication that the students were scared of using the technological tools at first though they became conversant with them as the lessons continued. The responses were an indication that students were engaged and motivated during the remote online lessons.

\section{Q2. How motivated were you during lessons?}

The responses of the participants were an indication that most of them were motivated during the lesson especially using some of the interactive tools for remote online learning. In the words of T12, he puts it;

"I am greatly motivated to learn especially because I love the way my teacher teaches"

Also, T10 added;

"There is more interaction between teachers and the students, moreover the teacher encourages all of us to use Mentimeter application to interact with each other"

Though most students show their zeal towards learning using online learning, some other students did not enjoy using any of the technological tools or resources. T3 stated;

"I miss the classroom, I miss talking with my teacher and I wish this pandemic will go so we can have lessons normally, I don’t enjoy anything”

\section{Another student stated;}

"How can I enjoy the class or be motivated when everything is done online, I'm not a fan of this online thing, I want to return to the real classroom". 
It was evident that most of the participants were motivated to learn during the online learning though a few complained that they wished that teaching and learning was returned to the traditional classroom.

\section{Q3. In what ways did the teacher motivate you during lessons?}

The participants indicated that the teacher always engaged them with interactions during each lesson, this encouraged the student to chat with one another during lessons. The participants also indicated that the teacher made use of projects and task to encourage them to learn, they suggested that use of projects and tasks made to them to interact with each other during the lessons to carry out the task collaboratively. They indicated that the use of games during the lessons and at the end of the lesson was so engaging during the lesson as they were immersed in completing the task as assigned by the gamethis was very helpful towards engaging the student during the remote online learning.

T8 puts it;

"the teacher was very clever in using games to make us lobe the lessons, he made us play educational games and answer questions with regards to the lesson, it was fun and exciting to see your achievement at the end of the games"

T4 stated;

"the teacher puts on in breakout rooms and encouraged us to use padlets to show our opinions during the discussion, it was fun and he was clever to use these"

T3 stated that;

'the teacher gave us projects and task to complete then he divided us into groups to complete the task, that was awesome, just as we do in the real classroom"

The responses of the student affirm to the strategies used by the teacher to keep the students motivated.

\section{Q4. What technological tools were most effective during the lesson?}

The participants thought that zoom break-out rooms, padlets, Mentimeter, nearpod were very effective while learning using online learning platforms. T4, T10, T11 affirmed to this assertion as they thought that these tools were very effective in engaging the students. T10 added;

"I enjoy the use of padlets, nearpod and Mentimeter, also the break out rooms was very interesting to join and it was easy to chat with everyone in the breakout room and contribute to the task assign, technology has done so much to assist education and assist us during this time"

More so, $\mathrm{T} 2, \mathrm{~T} 7, \mathrm{~T} 8$, and $\mathrm{T} 12$, indicated that the use of projects and task were the most effective tools used during the lesson. they stated that the use of projects and task helped everyone in actively participating throughout the lesson as it was observant that a few students were passive during interactive sessions. In the words of T8, she puts it; 
"The use of project was vital in getting everyone to participate during the lesson because some students were not active during the lesson but when the teacher used task and projects, dividing us into groups, all the groups became active as everyone participated".

Their responses are a clear indication that zoom break out rooms, padlets, Mentimeter, nearpods were the most effective tools used during online teaching.

\title{
Q5. What were the challenges of using these resources during remote online learning?
}

The student indicated that the sudden switch from traditional method to online was very stressful, According to $\mathrm{T}_{2}, \mathrm{~T}_{4}, \mathrm{~T}$, they indicated that it was very stressful for students to first register with all the resources and tools to be used for the online lessons from padlet, zoom, to Mentimeter application and this exercise was so stressful for them and they were left on their own to carry out these exercises. The participants indicated that poor internet connection was a strong challenge for most of the students as some of the virtual lessons experience poor video and audio quality which in some cases distorted the lessons, T6 added;

\author{
"I remember one of the lessons where you were cut off from the connection and everyone was saying \\ where is the teacher! It was funny for the teacher to lose connection, so the teachers experienced \\ what we were experiencing as well" \\ T1 stated; \\ "I joined the lesson late because I live in a small village where internet connection was so poor, what \\ could I do? But I'm glad I joined later on and enjoyed the class sessions" \\ Another adds; \\ "first, I think the university was selfish to immediately switch from traditional learning to online \\ without informing us and they expected us to comply immediately, there was no orientation rather \\ announcements, that was bad and affected most of us"
}

It is evident that the sudden switch to online learning, internet connections and stressful nature of the registration process was part of the challenges the students face during the remote online learning.

\section{DISCUSSION}

After careful analysis, the following findings were made; The study unveiled that instructors made use of an array of technological tools while engaging students during remote online learning. The study showed that that technological applications like Zoom, Padlets, Nearpod, Flipgrid, Mentimeter, Boom cards were predominantly used technological resources for student engagement, another tool like the vocaroo were not constantly used. These results go beyond previous reports to show that technological tools like Nearpods and Boom cards were effective for student engagement, affirming to other studies that suggest that the use of padlets were very effective in motivating student in an online learning scenario (Demosthenous et al., 2020; Beltrán-Martín, 2019; Kleinsmith, 2017). This result ties well with previous studies wherein it ispurported that student engagement could be with or without the use of technology (Ekblaw, 2016; Philp \& Duchesne, 2016) as this study affirmed that the use of technology is was one of the strategies applied by instructors for student engagement.

As suggested by Philp and Duchesne (2016), that student engagement may be with or without technology, this study uncovered that there were non-technological related strategies used by the instructors for student engagement which included the use of projects and peer teaching. Though the findings of the study suggested that project-based learning adopted by the teacher assists in stimulating interactions among students, peer teaching was not effective. Our results demonstrated that project-based learning was an effective means of engaging students in online learning as suggested by other similar studies (Toro- 
Troconis et al., 2019; Mavromoustakos \& Kamal, 2018), and stimulating interactions among the students (Karafil \& Oguz, 2019; Paulsen \& McCormick, 2020; Maia, Figueiredo, \& Serey, 2019), though contrary to the findings of the study, other researches thought that peer-based learning was effective in stimulating student engagement (Sridharan \& Bond, 2019; Ekblaw, 2016).

Furthermore, with regards to the effectiveness of resources used, the study found out that using these resources assisted in achieving lesson objectives which were a fundamental aspect for essence in student engagement, most studies affirm to this position (Redzuan et al., 2016; Ritchhart et al., 2011). The findings of the study also suggested that online teaching were instructional objectives were achieved, was an organized classroom that encouraged collaborative learning as asserted by researches (Mavromoustakos \& Kamal, 2018; Sridharan \& Bond, 2019). This suggests and affirms that conclusion of similar studies which posit that teaching was clear and understandable by the student as opined by studies that the use of resources breeds clarity is what is been taught (Groves et al., 2015; Beth, 2020). It was necessary to pinpoint that the results indicated that video and audio of the technological devices were of low quality and this affected the lessons at some point contradicting the opinion of Karafil \& Oguz (2019) who thought that most online learning experience high-quality audio and video during lessons. This study believes that one of the important challenges of online learning is internet connection related problems as suggested by Mavromoustakos \& Kamal (2018). This study opines that poor internet connection could be the reason for the poor quality of audio and video. Generally, the use of resources was deemed effective in engaging students during online learning.

\section{CONCLUSIONS}

Given the findings, the study makes the following conclusions and recommendations, this paper argued that the use of technological resources especially applications like zoom, padlets, flipgrid, Mentimeter, and Neapods were very effective tools that can be used for student engagement in online learning. This may be considered a further validation that other strategies like project-based learning can be incorporated into lessons to stimulate collaborative learning and interactions among the students. This allows the conclusion that there is a need for students to be kept motivated during the pandemic outbreak and this can be achieved through the use of these strategies for student engagement. It is difficult to arrive at any conclusions with regard to the use of Vocaroo as other studies seem to suggest it as a vital tool for student engagement though the result of the study concluded that Vocarro was not predominately used, the main conclusion that can be drawn is that this may be context-specific. In conclusion, it would appear that the use of peer teaching as suggested by studies was not effective for student engagement. This may be a result of student's personality traits and learning as well, this is another area of research that will examine the effect of personality traits and learning styles on the choice of online resources for student's engagement. The study concluded that there was some challenges witness during online learning which includes poor internet connection, which affected the audio and video quality of the resources used for student engagement and online learning.

In the light of this conclusion, the study recommends that educational facilities can liaise with telecommunication companies for the provision of high-speed internet connection for their student where the university provides free internet services for all the student. This could assist erase the issues of poor internet connections experience by both the instructor and students during the pandemic outbreak. The sudden switch from traditional classroom teaching to online learning did not give the instructor enough time to prepare for this adventure and this made the lessons of some of the instructors very boring, classroom management was difficult, and so on. The departmental heads must ensure that the instructors are well equipped with teaching resources, techniques, and strategies before commencing online learning. This will assist the instructors to be prepared for lessons thereby assisting and motivating the students who require help to set up their online learning portals. It is until then that the instructor can likewise sensitize the students on the basic requirements of online learning. This will reduce the panic among students and assist to reassure them of the university's assistance during the online learning process. There is a need for teachers to consider the personality traits of students and their learning styles in material selection. This is required also in an online learning scenario as this will assist the instructor in selecting 
the appropriate materials, resources, and tools that will assist in not only teaching the student but rather engaging them throughout the online learning process. These recommendations will foster learning and development among students especially during unprecedented times that we are experiencing right now.

\section{REFERENCES}

Beth, H. (March 2, 2020) Using Mentimeter in and out of the classroom. Learning Innovation Unit. From of https:// fetliu.net/blog/using-mentimeter-in-and-out-of-the-classroom/

Beltrán-Martín, I. (2019, July). Using Padlet for collaborative learning. [Conference], HEAD’19. 5th International Conference on Higher Education Advances. Universitat Politécnica de Valencia, Valencia, Spain. http://dx.doi. org/10.4995/HEAd19.2019.9188

Creswell,J.W.(2003). Research Design: Qualitative, Quantitative, and Mixed Methods Approaches (2 ed.). Sage Publications.

Daily Sabah (2020, March 14) Cyprus, north, and south, shuts borders to prevent the spread of coronavirus. https://cutt. ly/xhPuczu

Demosthenous, G., Panaoura, R., \& Eteokleous, N. (2020). The Use of Collaborative Assignment in Online Learning Environments: The Case of Higher Education. International Journal of Technology in Education and Science. 4(2). 108-117. https://doi.org/10.46328/ijtes.v4i2.43

Ekblaw, R. (2016). Effective use of group projects in online learning. Contemporary issues in education research, 9 (3), 121-128. https://doi.org/10.19030/cier.v9i3.9707

Fuchs, B. (2014). The writing is on the wall: using Padlet for whole-class engagement. LOEX Quarterly, 4O(4), 7-9. https://uknowledge.uky.edu/libraries_facpub/240/

Groves, M., Sellars, C., Smith, J., \& Barber, A. (2015). Factors affecting student engagement: A case study examining two cohorts of students attending a post-1992 university in the United Kingdom. International Journal of Higher Education, 4(2), 27-37. https://doi.org/10.5430/ijhe.v4n2p27

Hale, E., \& Ali, E (2019) Current Problems in the Turkish Republic of Northern Cyprus Education System, Sakarya university journal of education, 9(2), 282-303. https://doi.org/10.19126/suje.516474

Ironsi, S. C (2017) Effect of test anxiety on academic performance of EFL Learners. Lambert Academic Publishing

Karafil, B., \& Oğuz, A. (2019). Examining Factors Affecting Student Engagement in English Preparatory Classes According to Student Opinions. Üniversitepark Bülten. 8(2). 117-133. https://doi.org/10.22521/unibulletin.2019.82.2

Kleinsmith, C. L. (2017). The effects of using Padlet on the academic performance and engagement of students in a fifth-grade basic skills mathematics classroom, Rowan University. RowanDigitalWorks.

Maia, M., Figueiredo, J., \& Serey, D. (2019). Online Student Engagement: A Case Study in Teaching of Programming. 30(1). 51-60 https://doi.org/10.5753/cbie.sbie.2019.51

Mavromoustakos, S., \& Kamal, A. (2018). Student Engagement Practices for Computer Science Students in Online Learning Environments. In, A. V. Senthil Kumar, Optimizing Student Engagement in Online Learning Environments (pp. 83-99). IGI Global. https://doi.org/10.4018/978-1-5225-3634-5.choo4

Muhammed, I. A. (2020) North Cyprus confirms $6^{\text {th }}$ coronavirus. Anadolu Agency. https://cutt.ly/FhPixtm

Odo, C.R., \& Eze, C. U. (2017) Effect of Flipped Learning on Students Achievement in Computer Science in Tertiary Institution in Enugu State. London Journal of Research in Computer Science and Technology, 11(2), 45-50. https:// cutt.ly/jhPiQ9O

Paulsen, J., \& McCormick, A. (2020). Reassessing Disparities in Online Learner Student Engagement in Higher Education. Educational Researcher. 49(1), 20-29. https://doi.org/10.3102\%2Foo13189X19898690

Philp, J., \& Duchesne, S. (2016). Exploring engagement in tasks in the language classroom. Annual Review of Applied Linguistics, 36, 50-72. https://doi.org/10.1017/S0267190515000094

Ragusa, A. T., \& Crampton, A. (2018). Sense of connection, identity, and academic success in distance education: Sociologically exploring online learning environments. Rural Society, 27(2), 125-142, https://doi.org/10.1080/1037 1656.2018.1472914

Redzuan, F., Lokman, A. M., Ali Othman, Z., \& Abdullah, S. (2016). Kansei Design Model for Engagement in Online Learning: A Proposed Model. In, A. Abd Manaf, A. Zeki, M. Zamani, S. Chuprat, E. El-Qawasmeh, (Eds) Proceedings of the International Conference on Informatics Engineering and Information Science, (pp. 64-78). Informatics Engineering and Information Science. Springer, Berlin, Heidelberg. https://doi.org/10.1007/978-3-642-25327-0_7

Ritchhart, R., Church, M., \& Morrison, K. (2011) Making thinking visible: How to promote engagement, understanding, and independence for all learners. Jossey-Bass.

Shola G. O, Selira, K., \& Mustafa, I. (2011) Online Education in North Cyprus Universities: Case Study Eastern 
Mediterranean University. Procedia - Social and Behavioral Sciences 28, 536 - 541. https://doi.org/10.1016/j. sbspro.2011.11.103

Sridharan, B., \& Boud, D. (2019) The effects of peer judgments on teamwork and self-assessment ability in collaborative group work. Assessment and Evaluation in Higher Education. 44(6), 894-909. https://doi.org/10.1080/02602938.2 018.1545898

Stone, C. (2019) Online learning in Australian higher education: Opportunities, challenges, and transformations. Student Success 10(2), 1-11, p.2. https://doi.org/10.5204/ssj.v10i2.1299

The University of Kyrenia. (March 12, 2020) An important announcement by the university. From of https://cutt.ly/ WhPOKC2

Toro-Troconis, M., Alexander, J., \& Frutos-Perez, M. (2019). Assessing Student Engagement in Online Programmes: Using Learning Design and Learning Analytics. International Journal of Higher Education. 8(6), 171-183. https://doi. org/10.5430/ijhe.v8n6p171

Tugun, V., Uzunboylu, H., \& Ozdamli, F. (2017). Coding Education in a Flipped Classroom. Technology Education Management Informatics. 6(3), 599-606. https://doi.org/10.18421/TEM63-23

Yakın Doğu Üniversitesi (March 30, 2020) Announcement! Alternative fora live lessons: Google Hangout Meet. From of https://uzem.neu.edu.tr/

Yildirim, A. \& Simsek, H. (2011). Sosyal bilimlerde nitel arastirma yontemleri. Seckin Yayıncılık

\section{AUTHOR}

Chinaza Solomon Ironsi. Lecturer at the Department of English language teaching at the Near East University of Cyprus. His research interests focus on all areas of language teaching methods, reflective acts and education.

\section{Conflict of interest}

No potential conflict of interest is reported by the author.

\section{Funding}

No financial assistance from parties outside this article.

\section{Acknowledgment}

Special thanks to Professor Mohammad Keshavarz and Prof. Jim Kusch for their constant contributions towards achieving my academic dreams. Thanks, a lot. 